\title{
Prevention of Transfusional Trypanosoma cruzi Infection in Latin America
}

\author{
Gabriel A Schmunis
}

Pan American Health Organization, Regional Office of the World Health Organization, 525 Twenty-Third Street N.W., Washington, DC, 20037-2895, USA

Trypanosoma cruzi is a protozoan infection widely spread in Latin America, from Mexico in the north to Argentina and Chile in the south. The second most important way of acquiring the infection is by blood transfusion. Even if most countries of Latin America have law/decree/norms, that make mandatory the screening of blood donors for infectious diseases, including T. cruzi (El Salvador and Nicaragua do not have laws on the subject), there is usually no enforcement or it is very lax.

Analysis of published serologic surveys of T. cruzi antibodies in blood donors done in 1993, indicating the number of donors and screening coverage for $\mathrm{T}$. cruzi in ten countries of Central and South America indicated that the probability of receiving a potentially infected transfusion unit in each country varied from 1,096 per 10,000 transfusions in Bolivia, the highest, to 13.02 or 13.86 per 10,000 transfusions in Honduras and Venezuela respectively, where screening coverage was $100 \%$. On the other hand the probability of transmitting a T. cruzi infected unit was 219/10,000 in Bolivia, 24/10,000 in Colombia, 17/10,000 in El Salvador, and around 2-12/10,000 for the seven other countries.

Infectivity risks defined as the likelihood of being infected when receiving an infected transfusion unit were assumed to be $20 \%$ for T. cruzi. Based on this, estimates of the absolute number of infections induced by transfusion indicated that they were 832, 236, and 875 in Bolivia, Chile and Colombia respectively. In all the other countries varied from seven in Honduras to 85 in El Salvador.

Since 1993, the situation has improved. At that time only Honduras and Venezuela screened 100\% of donors, while seven countries, Argentina, Colombia, El Salvador, Honduras, Paraguay, Uruguay and Venezuela, did the same in 1996. In Central America, without information from Guatemala, the screening of donors for $\mathrm{T}$. cruzi prevented the transfusion of 1,481 infected units and the potential infection of 300 individuals in 1996. In the same year, in seven countries of South America, the screening prevented the transfusion of 36,017 infected units and 7, 201 potential cases of transfusional infection.

Key words: Trypanosoma cruzi - Chagas disease - blood transfusion - serology - donors screening - prevention Latin America

Trypanosoma cruzi is a protozoan infection widely spread in Latin America, from Mexico in the north to Argentina and Chile in south. Years after the infection takes place, $T$. cruzi may be detected in the blood in as many a $50 \%$ of those infected (Schenone et al. 1968). Thus, it is not unexpected that $T$. cruzi could be transferred from an infected to a noninfected person by blood transfusion. Fortunately, only some of the recipients of infected blood become infected. Infection rates among blood recipients vary from $1.4 \%$ to $18 \%$ in Argentina, Brazil, and Chile, and can be up to $48 \%$ in Bolivia (Rohwedder 1969, Cerisola et al. 1972, Diaz 1979, Zuna et al. 1985). Transmission by blood transfusion is considered the second most

Fax: +202-9743688. E-mail: schmunig@paho.org Received 9 June 1999

Accepted 9 August 1999 common way of acquiring this infection (Schmunis 1985, WHO 1990).

For the past six decades, economic hardship in Latin America has stimulated migration to urban areas. Therefore, what used to be a rural disease is now often present in cities, where an average, close to $75 \%$ of the population of Latin America now lives (Organización Panamericana de la Salud 1998). Migration from rural to urban areas, while decreasing the rural population exposed to infected vectors (Quinteros et al. 1990), increases the possibility of acquiring $T$. cruzi infection by blood transfusion in cities (Schmunis 1985, 1989, 1991, World Health Organization 1990).

Economic hardships and/or political turmoil have increased migration among Latin American countries, and from Latin America countries to the USA (Schmunis 1994). The United States 1990 census indicated that more than 7 million people from countries endemic for $T$. cruzi reside in the United States (Statistical Abstract of the USA 
1992). In addition, 250,000 are living in Europe, 80,000 in Australia, and 150,000 in Japan (Schmunis 1994). Therefore, it is not surprising that transfusion acquired $T$. cruzi infection is a potential problem in non endemic countries.

Transfusional infection is a significant public health problem. Even if most countries of Latin America have laws, regulations and guidelines that make the screening of blood donors for infectious diseases mandatory, including T. cruzi (El Salvador and Nicaragua do not have laws on the subject), there is usually no enforcement or it is very lax. While in most countries serology for $T$. cruzi is mandatory throughout, in Chile (Ministry of Health, Chile 1993) and Mexico (Guzman Bracho et al. 1998) serology in blood banks is mandatory only in endemic areas. Furthermore, screening in Mexico is not routinely done in all endemic states. In places like Santa Cruz, Bolivia, where the prevalence of $T$. cruzi antibodies in the population is above $50 \%$, the possibility of acquiring $T$. cruzi infection through a blood transfusion is obvious (Zuna et al. 1985, Carrasco et al. 1990).

\section{PREVALENCE}

Serologic surveys of T. cruzi antibodies in blood donors have been available since 1949 . The results of almost all the surveys carried out between 1949 and 1980, and a few other surveys reported since the 80's have been reviewed elsewhere (Schlemper Jr. 1978, Dias 1979, Schmunis 1991, 1994, Wendell \& Dias 1992). Information available from Brazil compares the range of prevalence of $T$. cruzi in different regions with the range of prevalence of other diseases transmitted through blood (Ministry of Health, Brazil 1990-1991).

Available data up to 1992 indicate that prevalence of $T$. cruzi infection in blood donors was around 25\% in Bolivia; 5\% to 6\% in Argentina and Paraguay; $3 \%$ to $5 \%$ in El Salvador and Guatemala; $1 \%$ to $2 \%$ in Brazil, Chile, Colombia, Honduras and Venezuela; and, $<1 \%$ in Ecuador and Nicaragua. Data on serological prevalence of $T$. cruzi in blood donors from Argentina (Schmunis 1985, Perez \& Segura 1989, Rosestein Campanini et al. 1993), a Brazilian state (Andrade et al. 1989), Honduras (Ponce 1992) and Uruguay (Franca 1986, Arago 1986) correlated well in most areas with the results of serological surveys, indicating morbidity in the general population of those locations (Segura et al. 1985, Andrade et al. 1989, Salvatella et al. 1989, Ponce 1992).

All of the above were partial data, because national data were not available. Nevertheless these data were extremely useful because establishing the prevalence of $T$. cruzi antibodies in blood donors may provide quick information on the preva- lence of the infection in a given geographical area. This is especially the case in countries where knowledge of the status of human infection is lacking, and where control measures for vector or transfusional transmission of $T$. cruzi are not implemented. These data would also indicate the need to implement control strategies for the prevention of transfusional transmission (Schmunis 1991).

\section{INCIDENCE}

The real incidence of $T$. cruzi acquired through blood is unknown because most cases are either inapparent or T. cruzi is not recognized as the etiological agent (Schmunis 1985, 1991). Danger may come not only from whole blood, but from packed red cells, platelets, white cells, fresh frozen plasma, and cryoprecipitate. On the other hand, the use of lyophilized products seems to be safe (Cerisola et al. 1972, Schlemper 1978, WHO 1990).

In Brazil, where 4 million transfusions are performed yearly, an annual incidence of 10,000 to 20,000 cases has been suggested (Amato Neto 1984, cited in Amato Neto 1993). These estimates correspond to the decade of 1970 (Wendell \& Diaz 1992). Only the São Paulo metropolitan area may have contributed 10,000 cases a year (Camargo 1977, cited in Dias 1979). It currently seems that those numbers were exaggerated. The number of donors with positive serology for $T$. cruzi was 55,000; of those, 11,000 were not screened; therefore, it was estimated that between 1,500 to 3,000 individuals, per year, acquired the infection through transfusion (Amato Neto 1993).

The risk of receiving infected blood will be proportional to the prevalence of the infection in the donor population and to the number of transfusions performed. Therefore, polytransfused individuals, like hemophiliacs, patients with other hematologic disorders, or those undergoing dialysis, are at greater risk. In Argentina, 50\% of hemophiliacs became infected after receiving 30 or more transfusions each from a blood bank with a $2 \%$ prevalence of positive serology for $T$. cruzi (Cerisola et al. 1972). In another study, in Chile, it was found that $15 \%$ of individuals who had multiple transfusions, had positive serology for T. cruzi, while the general population was $2 \%$ positive (Lorca et al. 1988). Polytransfused individuals from a blood bank with $2 \%$ positive serology for T. cruzi were 8.7 times more likely to be positive than individuals who did not receive transfusions. On the other hand, the theoretical risk of transmission for individuals receiving only one transfusion may vary from $0.15 \%$ to $0.6 \%$ (Atias et al. 1984) to $20 \%$ (WHO 1990) or higher (Zuna et al. 1985).

In any case information available up to 1992 have some limitations. Countries lacked a country 
wide information system on the number of donors and the number of screened donors, both needed to calculate screening coverage. If that information had been available, coupled with a knowledge of the prevalence of the infection, it would have been possible to calculate the risk of acquiring $T$. cruzi infection through a transfusion, and the potential number of cases transmitted by blood (Schmunis et al. 1998).

In blood banks, the aim of tests for diagnosis of $T$. cruzi is screening, so as to eliminate all units of blood potentially infected. The purpose of performing more than one serological test for screening, was to avoid introducing false negatives in the blood supply by detecting all potentially positive units (those that could have been negative by one test). In fact, adding tests increases the sensitivity as well as the specificity of the diagnosis. Each methodology and antigen(s) used in the different tests is able to detect antibodies of different specificities. Actually, a limitation of the data obtained, was that different type of tests for T. cruzi serology were used in the donor population in the different countries.

Several serological techniques are being used for detection of T. cruzi antibodies: complement fixation (CF); indirect hemagglutination (IHA); indirect immunofluorescence (IIF), direct agglutination (DA), and enzyme linked immunoabsorbent assay (ELISA). CF test is the more difficult to standardize and its use must be discouraged. Sensitivity of any single test alone is $\geq 98.91 \%$, and specificity $\geq 98.52 \%$. Using three (CF, IIF and IHA) or the four tests increases sensitivity to $100 \%$, but slightly decreases specificity or the latter remains the same (Takei 1992, Wendell \& Gonzaga 1993).

Although ELISA tests are easy to standardize and have the advantage of automatization, they need higher concentration of antibodies in the sample to correlate well with the IIF (Wendell \& Gonzaga 1993). Considering as positive only those sera that were positive by IHA and IIF tests, the ELISA gave two false negative and 41 false positive results. The overall sensitivity of ELISA was considered to be $96.3 \%$ (Andrade et al. 1992a). In another study in which an ELISA test using a recombinant antigen and four commercially available antigens were compared with conventional serology done by IIF and IHA, it was concluded that ELISA improved the serologic diagnosis of Chagas. In addition, the ELISA best allowed for a considerable reduction in the number of sera in which there was disagreements in the results obtained by different tests in conventional serology (Carvalho et al. 1993). Evaluation of commercial ELISA indicated that the sensitivity varied from 93\% to $100 \%$ (Oelerman et al. 1998).
In the real world however, another limitation of the data obtained from countries was the unreliability of the commercial kits, whose sensitivity and specificity varied widely as was shown for IFI, IHA, and ELISA in Chile (Lorca et al. 1992, 1994) and for the IHA in Brazil (Saez-Alquezar et al. 1997). This problem is compounded in most countries by the lack of quality control systems. A report from Brazil shows that, in spite of serological screening, 12 of 1,513 samples tested were false-negative (Andrade et al. 1992b) In a performance evaluation of 57 major public blood banks, there were $3.7 \%$ false-negative results when testing four panels of sera on a total of 108 samples. Most false-negative results were reported by banks using the IHA (Saez-Alquezar et al. 1997).

A recent report (Schmunis et al. 1998) analyzed national data (OPS 1994, 1995a,b, 1996) on coverage of blood donors screening in four Central American countries (El Salvador, Guatemala, Honduras and Nicaragua) and six countries in South America (Bolivia, Chile, Colombia, Ecuador, Paraguay and Venezuela). With the exception of Chile (Ministerio de Salud, Chile 1996), which reported a fractionation index of 1.85 , for all the other countries it was assumed that every blood donation corresponded to a subsequent transfusion to one recipient. Estimates were based on results of screening activities as reported by the countries.

Table I presents the number of donors, screening coverage and prevalence rates for $T$. cruzi antibodies among blood donors in each one of the ten countries. For $T$. cruzi infection, only Venezuela and Honduras screened $100 \%$ of donors, prevalence rates per one thousand donors ranged from $0.20 \%$ in Ecuador and $0.24 \%$ in Nicaragua, to $5.30 \%$ in Paraguay, and $14.8 \%$ in Bolivia. At that time (1993), Costa Rica, Peru and Mexico had not yet introduced routine screening for $T$. cruzi in blood banks. Information from Argentina indicated that screening coverage for T. cruzi was not complete and in Brazil, screening was routinely done in blood banks from the public sector but no information was available from the private sector.

Estimates of the potential infectivity of the blood supply are shown in Table II. The probability of receiving a potentially infected transfusion unit in each country varied from a maximum of 1096 per 10,000 transfusions in Bolivia, to 1,048 in Nicaragua or around 13 per 10,000 transfusions in Honduras and Venezuela, where screening coverage was $100 \%$. On the other hand, the probability of getting an infection through an infected unit was 219 per 10,000 in Bolivia, 24 per 10,000 in Colombia, 17 per 10,000 in El Salvador, and between 2 and 12/10,000 for the seven other countries (Schmunis et al. 1998). 
TABLE I

Latin America 1993

Serology for Trypanosoma cruzi in blood donors ${ }^{a}$

\begin{tabular}{lrrr}
\hline Country & \multicolumn{1}{c}{$\begin{array}{c}\text { No. } \\
\text { of } \\
\text { donors }\end{array}$} & $\begin{array}{c}\text { Screening } \\
\text { coverage } \\
\text { (\% of donors } \\
\text { with serology) }\end{array}$ & $\begin{array}{c}\text { Prevalence } \\
(00)\end{array}$ \\
\hline Bolivia & 37,948 & 29.40 & 14.81 \\
Chile & 217,312 & 76.70 & 1.20 \\
Colombia & 352,316 & 1.40 & 1.20 \\
El Salvador & 48,048 & 42.50 & 1.47 \\
Ecuador (1994) & 98,473 & 51.0 & 0.20 \\
Guatemala & 45,426 & 75.00 & 1.40 \\
Honduras & 27,885 & 100.00 & 1.24 \\
Nicaragua & 46,001 & 58.40 & 0.24 \\
Paraguay (1994) & 32,893 & 95.47 & 5.30 \\
Venezuela & 203,316 & 100.00 & 1.32 \\
\hline
\end{tabular}

$a$ : countries that provided national information.

Infectivity risks, defined as the likelihood of being infected when receiving an infected transfusion unit, were assumed to be $20 \%$ for T. cruzi (WHO 1990). Based on these estimates, the absolute number of infections induced by transfusion was 832 , 236, and 875 in Bolivia, Chile and Colombia, respectively. In all the other countries this number varied from seven in Honduras to 85 in El Salvador. The ratio infection/donation for each country indicated that one T. cruzi infection might have been transmitted for every 46 (Bolivia) to 4,924 (Ecuador) donations (Table II) (Schmunis et al. 1998).

However, even in those countries with $100 \%$ screening coverage there is a potential for receiving an infected transfusion, because of the residual infectivity originated in the lack of sensitivity of the reagents available for diagnosis (Schmunis et al. 1998).

In all countries there is a risk that blood recipients may become infected with T. cruzi. Even in those countries where official data was not available, like for Costa Rica, Mexico and Peru it is possible to speculate on the status of T. cruzi as a danger for the blood supply. Previous data on the seroprevalence of $T$. cruzi in blood donors from Costa Rica from 1983-1985 (Schmunis 1994), suggest that a risk may exist. Information from Mexico, where there are approximately 850,000 donations yearly, suggests that 12,750 donors are infected with T. cruzi. Assuming that only $15 \%$ of donors are infected, would indicate that 1912 recipients were potentially infected with $T$. cruzi (Guzman Bracho et al. 1998). Data from a survey among donors in Lima indicated a prevalence of $2.36 \%$ (OPS 1994). If this is the real prevalence in that city, the number of tainted units transfused would have been 1,872 in 1993 , while the number of infected individuals through blood transfusion could have been 375 . On the other hand, if blood had not been screened at all in the ten countries that reported $T$. cruzi prevalence, the number of infected units transfused would have amounted to several thousands.

This 1993 report provided an overview of the potential risk of receiving tainted blood in different Latin American countries. However, some limitations of the data must be taken into account. As the laboratory procedures employed in the ten countries may differ in sensitivity and specificity, comparisons among them are not straightforward. In addition, results of the screening are influenced by the existence of an organized system of quality

TABLE II

Trypanosoma cruzi transfusion transmitted infection ${ }^{a}$

\begin{tabular}{lcccc}
\hline Country & $\begin{array}{c}\text { Probability of } \\
\text { receiving an infected } \\
\text { transfusion } \\
(\text { X0000) }\end{array}$ & $\begin{array}{c}\text { Probability of getting } \\
\text { a transfusion } \\
\text { transmitted infection } \\
(\text { X0000) }\end{array}$ & $\begin{array}{c}\text { Absolute no. of } \\
\text { transfusion } \\
\text { transmitted } \\
\text { infections }\end{array}$ & $\begin{array}{c}\text { Ratio infections/ } \\
\text { donations }\end{array}$ \\
\hline Bolivia & 1096.38 & 219.28 & 832 & $1: 46$ \\
Chile & 29.36 & 5.87 & 236 & $1: 92$ \\
Colombia & 124.24 & 24.85 & 875 & $1: 403$ \\
Ecuador & 10.29 & 2.06 & 20 & $1: 4,924$ \\
El Salvador & 88.75 & 17.75 & 85 & $1: 565$ \\
Guatemala & 36.75 & 7.35 & 33 & $1: 1,377$ \\
Honduras $c$ & 13.02 & 2.60 & 7 & $1: 3,984$ \\
Nicaragua & 10.48 & 2.10 & 10 & $1: 4,600$ \\
Paraguay & 62.37 & 12.47 & 41 & $1: 802$ \\
Venezuela $^{c}$ & 13.86 & 2.77 & 57 & $1: 584$ \\
\hline
\end{tabular}

$a$ : Schmunis et al. 1998. All data from 1993, except for Ecuador and Paraguay that were 1994; $b$ : probability for 10,000 transfussions. $c$ : residual infection only as screening coverage is $100 \%$. 
control and proficiency testing for the serology and for the evaluation of the diagnostic kits, which most countries lacked in 1993-1994. In some cases, the risk of transfusion related infection is overestimated considering that recipients might be already infected. This is most significant for $T$. cruzi infection in Bolivia where the seroprevalence in the general population is sometimes higher than $20 \%$ (Zuna et al. 1985, Carrasco et al. 1990).

In any case, the findings stress the importance of having an information system that allows for determining the status of the screening process for infectious diseases in the blood supply. This information, which was only partially available before (Linares \& Vinelli 1991, Schmunis 1991, Wendell \& Dias 1992), serves as baseline to which future achievements could be measured.

Since 1993, the situation has improved in several countries. Table III shows the screening coverage in 17 countries of the Americas, from 1993 to 1997. The following conclusions are based on data from 1993-1996 already published (OPS 1997, 1998, Schmunis et al. 1998b), analyzed following the methodology reported previously (Schmunis et al. 1998). They also assume the best scenario: sensitivity and specificity of diagnostic test to be $100 \%$; that all test were made correctly; that a system of quality control was in place; and that prevalence of donors screened were the same as in unscreened donors. Consequently, in Central America, except for Guatemala, the screening of donors for $T$. cruzi prevented the transfusion of
1,481 units and the potential infection of 300 individuals (Table IV). In the same year, in seven countries of South America, screening prevented the transfusion of 36,017 infected units and 7, 201 potential cases of transfusional infection (see Table IV). The bottom line is that two countries, Honduras and Venezuela, screened $100 \%$ of donors in 1993, while seven countries, Argentina, Colombia, El Salvador, Honduras, Paraguay, Uruguay and Venezuela, did the same in 1997.

\section{PREVENTING T. CRUZI TRANSMISION THROUGH TRANSFUSION}

Some governments do not have the will or the capacity for implementing prophylactic measures or to enforce them. On the other hand, while the number of transfusions is unjustifiably high, the medical profession at large, and even those devoted to blood banking, seem not to pay enough attention to the possibility that $T$. cruzi could be transmitted by this mean (Dias 1979, Diaz \& Brener 1984, Schmunis 1991, Dias 1992). Therefore, health personnel, in particular, and the public, in general, must be educated on the possibility that $T$. cruzi could be transmitted by blood.

Mandatory serology must be implemented in all countries where $T$. cruzi is endemic ideally using at least two serological tests. There should be a ban on paid blood donors; voluntary altruistic donations must be promoted; and a program of quality control for serology must be implemented (Dias 1979, 1992, Diaz \& Brener 1984, Schmunis 1991).

TABLE III

Number of blood donors and screening coverage in countries of the Americas

\begin{tabular}{lccc}
\hline Countries & Year(s) & No. of donors & $\begin{array}{c}\text { \% screening } \\
\text { coverage }\end{array}$ \\
\hline Argentina $^{a}$ & $1993-1997$ & $742,000-850,000$ & $58-100$ \\
Belize & 1997 & 2,796 & 0 \\
Bolivia & $1993-1996$ & $19,987-40,056$ & $30-71$ \\
Brazil $^{b}$ & 1997 & $1,605,001$ & 100 \\
Chile & $1993 / 1996 / 1997$ & $217,312-228,801$ & $60-77$ \\
Colombia+ & $1993-1997$ & $332,540-422,300$ & $1.40-100$ \\
Costa Rica & $1995-1997$ & $44,754-58,436$ & $0-13$ \\
Ecuador & $1994-1997$ & $98,473-110,619$ & $51-91$ \\
El Salvador & $1993-1997$ & $34,091-55,069$ & $42-100$ \\
Guatemala & 1993 & 45,026 & 75 \\
Honduras & $1993-1997$ & $27,660-33,958$ & $85-100$ \\
Nicaragua & $1993-1997$ & $43,887-48,030$ & $51-68$ \\
Panama & $1994-1996$ & $26,333-41,888$ & $1.14-24$ \\
Paraguay & $1994-1997$ & $32,893-39,904$ & $83-100$ \\
Peru & 1997 & 203,690 & $0-60$ \\
Uruguay & $1994-1997$ & $110,319-115,490$ & $52-100$ \\
Venezuela & $1993-1997$ & $204,316-262,295$ & 100 \\
\hline
\end{tabular}

$a$ : information not available for 1994; $b$ : information on percentage of screened donors and prevalence not available for 1,044,673 donors from the private sector; $c$ : information not available for 1996 . 
TABLE IV

Prevention of T. cruzi infection by blood screening in Latin America, by country, 1993-1996

\begin{tabular}{|c|c|c|c|c|}
\hline Country & 1993 & 1994 & 1995 & 1996 \\
\hline \multicolumn{5}{|l|}{ Argentina } \\
\hline No. of infected units discarded & 27,809 & ? & 38,189 & 27,591 \\
\hline No. of cases prevented & 5,561 & ? & 7,638 & 5,518 \\
\hline \multicolumn{5}{|l|}{ Bolivia } \\
\hline No. of infected units discarded & 1,650 & 2,872 & 2,002 & 3,003 \\
\hline No. of cases prevented & 330 & 574 & 400 & 600 \\
\hline \multicolumn{5}{|l|}{ Chile } \\
\hline No. of infected units discarded & 2,000 & ? & ? & 1,305 \\
\hline No. of cases prevented & 400 & ? & ? & 261 \\
\hline \multicolumn{5}{|l|}{ Colombia } \\
\hline No. of infected units discarded & 59 & 658 & 2,217 & ? \\
\hline No. of cases prevented & 12 & 132 & 443 & ? \\
\hline \multicolumn{5}{|l|}{ Costa Rica } \\
\hline No. of infected units discarded & ? & ? & 47 & 47 \\
\hline No. of cases prevented & ? & ? & 9 & 9 \\
\hline \multicolumn{5}{|l|}{ Ecuador } \\
\hline No. of infected units discarded & 1,004 & 100 & 76 & 67 \\
\hline No. of cases prevented & 201 & 20 & 15 & 13 \\
\hline \multicolumn{5}{|l|}{ El Salvador } \\
\hline No. of infected units discarded & 300 & 741 & 1,192 & 1,211 \\
\hline No. of cases prevented & 60 & 748 & 238 & 242 \\
\hline \multicolumn{5}{|l|}{ Guatemala } \\
\hline No. of infected units discarded & 417 & ? & ? & ? \\
\hline No. of cases prevented & 95 & ? & ? & \\
\hline \multicolumn{5}{|l|}{ Honduras } \\
\hline No. of infected units discarded & 346 & 357 & 489 & 98 \\
\hline No. of cases prevented & 69 & 71 & 98 & 24 \\
\hline \multicolumn{5}{|l|}{ Nicaragua } \\
\hline No. of infected units discarded & 64 & 122 & 122 & - \\
\hline No. of cases prevented & 13 & 24 & 24 & - \\
\hline \multicolumn{5}{|l|}{ Paraguay } \\
\hline No. of infected units discarded & 1,603 & 1,288 & 1,647 & 1,486 \\
\hline No. of cases prevented & 321 & 251 & 329 & 297 \\
\hline \multicolumn{5}{|l|}{ Panama } \\
\hline No. of infected units discarded & $?$ & ? & 9 & 9 \\
\hline No. of cases prevented & $?$ & ? & 2 & 2 \\
\hline \multicolumn{5}{|l|}{ Uruguay } \\
\hline No. of infected units discarded & 458 & 684 & 658 & 697 \\
\hline No. of cases prevented & 92 & 136 & 132 & 139 \\
\hline \multicolumn{5}{|l|}{ Venezuela } \\
\hline No. of infected units discarded & 2,697 & 2,690 & 1,701 & 1,868 \\
\hline No. of cases prevented & 539 & 538 & 340 & 373 \\
\hline
\end{tabular}

Few countries use more than one test for blood donor screening. Data from Argentina indicated that $50 \%$ of 423 centers performed one serological technique for screening (Perez \& Segura 1989). A similar survey done in Brazil, covering 850 counties in 1988-1989, indicated that there were 1,525 health services that provided some sort of blood transfusion services. Of these 882 did serology for $T$. cruzi. Of the latter, $55 \%$ performed one serological test for diagnosis, while 26.8 and $12.2 \%$, respectively, did two or three tests (Dias 1992, Morales-Souza et al. 1994).

The situation, however, did improve. In the State of São Paulo, 95.3\% of 64 blood services 
performed serology for T. cruzi in 1990, while only $69 \%$ did so in 1988 . The percentage of services that made serology for syphilis, hepatitis B and HIV were $92.2 \%, 92 \%$ and $90 \%$, respectively, in 1990, against $70.4 \%, 67.6 \%$, and $63.4 \%$ in 1988 . On the other hand, from 61 services that did T. cruzi serology in $1990,11.5 \%$ did only one test, $55.7 \%$ performed two, and $32.8 \%$, three or more tests (Valerio-Wanderley et al. 1992).

In areas with a high percentage of potential donors infected, even when the facilities to do serological tests are available, blood with positive serology cannot be discarded, because the blood supply may be reduced. In those areas, the only measure capable of preventing transfusional infection is the addition of gentian violet to the blood. This dye kills trypomastigotes in vitro at $4^{\circ} \mathrm{C}$ (Nussenzweig et al.1953, Diaz 1992). When used in concentrations of $125 \mathrm{mg} / 500 \mathrm{ml}$, and the blood is stored for $24 \mathrm{hr}$ before use, transmission is avoided (Nussenzweig et al. 1953, Shlemper Jr 1978, Diaz 1979, 1992, Diaz \& Brener 1984). This strategy has been used extensively in some countries, like Brazil, without apparent side effects, except that patients may become stained for short periods of time (Schmunis 1985, 1989).

The Aids epidemic has increased the awareness of national authorities from endemic countries of the need for serological screening to prevent transfusionally transmitted diseases. This will also improve the situation in relation to $T$. cruzi (as well hepatitis B and C). Meantime, the number of infected individuals with $T$. cruzi will decrease slowly because the full impact of the measures implemented to interrupt vectoral and blood transmission will take years to materialize. Therefore, implementation of measures to prevent blood transmission of T. cruzi as well as the presence of patients with Chagas disease, still will constitute a burden for the health services for the years to come.

\section{ACKNOWLEDGEMENT}

To editorial assistance of Mrs Maria Roxane Gonzalez.

\section{REFERENCES}

Amato Neto V 1993. Conduta frente ao doador chagasico. Rev Soc Brasil Med Trop 26 (Suppl. 11): 86-87.

Andrade ALSS, Martelli CMT, Pinheiro ED, Santana CL, Borges FP, Zicker F 1989. Rastreamento sorologico para doenças infecciosas em banco de sangue como indicador de morbidade populacional. Rev Saúde Públ São Paulo 23: 20-25.

Andrade ALSS, Martelli CMT, Luquetti AO, Oliveira OS, Silva SA, Zicker F 1992a. Serologic screening for Trypanosoma cruzi among blood donors in central Brazil. PAHO Bull 26: 157-164.
Andrade ALSS, Zicker F, Luquetti AO, Oliveira RM, Silva SA, Souza JMP, Martelli CMT 1992b. Surveillance of Trypanosoma cruzi transmission by serological screening of school children. Bull WHO 70: 625-629.

Arago A 1986. Transmisión de la enfermedad de Chagas por transfusión. Rev Med Uruguay 2: 193-197.

Atias A, Lorca M, Canales M, Mercado R, Reyes V, Child R 1984. Enfermedad de Chagas: Transmisión por transfusión sanguinea en Chile. Bol Hosp San Juan de Dios (Santiago) 31: 301-306.

Carrasco R, Miguez H, Camacho C, Echalar L, Rovollo S, Ampuero T, Dedet JP 1990. Prevalence of Trypanosoma cruzi infection in blood banks of seven departments of Bolivia. Mem Inst Oswaldo Cruz 85: 69-73.

Carvalho MR, Krieger MA, Almeida E, Oelemann W, Shikanai-Yussuda MA, Ferreira AW, Pereira JB, Saez-Alquezar A, Dorehiac-Llacer PE, Chamone DF, Goldenberg S 1993. Chagas' disease diagnosis: evaluation of several tests in blood screening. Transfusion 33: 830-834.

Cerisola JA, Rabinovich A, Alvarez M, Di Corleto CA, Pruneda J 1972. Enfermedad de Chagas y la transfusión de sangre. Bol Oficina Sanit Panam 73: 203-221.

Dias JCP 1979. Mecanismos de transmissão, p.152-174. In Z Brener \& ZA Andrade (eds), Trypanosoma cruzi e Doenca de Chagas, Guanabara Koggan, Rio de Janeiro.

Dias JCP 1992. Chagas' disease and blood transfusion in endemic areas, p. 135-142. In S Wendel, Z Brener, ME Camargo \& A Rassi (eds), Chagas' Disease (American Trypanosomiasis): its Impact on Transfusion and Clinical Medicine, ISBT, São Paulo.

Dias JCP, Brener S 1984. Chagas' disease and blood transfusion. Mem Inst Oswaldo Cruz 79 (Suppl.): 39-147.

Franca ME 1986. La enfermedad de Chagas en el Uruguay en los últimos veinte años. Rev Med Uruguay 2: 125-131.

Guzman Bracho C, Garcia LG, Verdugo JF, Martinez SG, Cosme MT, Melgar CR, Cestrejon OV 1998. Riesgo de transmision de Trypanosoma cruzi por transfusion de sangre en Mexico. Rev Panam Salud Salud Publica 4: 94-98.

Linares J, Vinelli E 1994. Taller Latinoamericano de Servicios de Transfusión Sanguínea y Óptimo Uso de los Recursos, Cruz Roja Finlandesa, 167 pp.

Lorca M, Lorca J, Child R, Attias A, Canales M, Lorca E, Gutierrez J 1988. Prevalencia de la infección por Trypanosoma cruzi en pacientes politransfundidos. Rev Med Chile 116: 112-116.

Lorca M, Child R, Garcia AC, Silva MC, Osorio J, Atias AM 1992. Evaluación de reactivos comerciales empleados en el diagnóstico de la enfermedad de chagas en bancos de sangre de Chile. 1. Selección de reactivos. Rev Med Chile 120: 420-442.

Lorca M, Child R, Garcia A, Silva MG, Martinez LP, Jerez GM, ToledoI, Mezzano DA 1994. Evaluación de reactivos comerciales empleados en el diagnóstico de la enfermedad de Chagas en bancos de sangre de 
Chile. II Aplicación rutinaria. Rev Med Chile 122: 925-931.

Ministério da Saúde, Brasil 1990-1991. Coordenação de Sangue e hemoderivados. Relatorio de atividades: Anexo IX. Ministerio de Salud, Chile 1990-1991. Diagnóstico de la situación de los bancos de sangre y medicina transfusional en Chile 1993. Ser Inf Técnicos No. 14.

Moraes-Souza H, Wanderley DM, Brener S, Nescimento RD, Antunes CM, Dias JC 1994. Hemoterapia e doenca de chagas transfusional no Brasil. Bol Ofic Sanit Panam 116: 406-418.

Nussenszweig V, Sonntag R, Biancalana A 1953. Ação de corantes trifenilmetanicos sobre o Trypanosoma cruzi in vitro. Emprego da violeta de genciana na profilaxia da transmissão da moléstia de Chagas por transfusão de sangue. O Hospital 4: 731-744.

Oelerman WMR, Teixeira MG, Da Costa GCV, BorgesPereira J, De Castro JA, Coura JR, Peralta JM 1998. Evaluation of three commercial enzyme-linked immunosorbent assays for diagnosis of Chagas disease. J Clin Microbiol 36: 2423-2427.

OPAS-Organización Panamericana de la Salud 1994. Taller para el control de calidad de sangre en transfusiones: serología para la detección de Chagas, hepatitis B y C, sifilis y HIV/SIDA. Document OPS/ HPC/HCT/94.42.

OPAS-Organización Panamericana de la Salud 1995a. Simposio internacional sobre control de calidad en bancos de sangre del Cono Sur y de Brasil. Informe final OPS/HCP/HCT/95.55.

OPAS-Organización Panamericana de la Salud 1995b. Países andinos. Taller sobre control de calidad de sangre en transfusiones:serología para la detección de hepatitis B y C, sifilis, tripanosomiasis americana y VIH/SIDA. Document OPS/HCP/HCT/95-61.

OPAS-Organización Panamericana de la Salud 1996. Taller sobre control de calidad en serología de bancos de sangre. OPS/HCP/HCT/96/79.

OPAS-Organización Panamericana de la Salud 1997. Situación de los bancos de sangre en la Región de las Américas 1994-1995. Bol Epidemiol OPAS 18: 11-12.

OPAS-Organización Panamericana de la Salud 1998a. La Salud en las Américas, Pub Sci No. 569 p.

OPAS-Organización Panamericana de la Salud 1998b. Situación de los bancos de sangre en América Latina 1996: Marcadores serológicos para enfermedades transmisibles a donantes de sangre. Bol Epidemiol 19: 11-13.

Perez A, Segura E 1989. Transfusión de sangre y transmission de la infección chagásica en Argentina. Rev Arg Transf 15: 127-132.

Ponce E 1992. Control de la transmision transfusional. La enfermedad de Chagas en Honduras, Ministerio de Salud Publica. OPS/OMS. Serie diagnostica 6: 31-38.

Quinteros ZT, Troncoso MC, Arnesi N, Boggio G, Sanchez S 1990. Comportamientos migratorios en donantes de sangre y su relación con infección chagásica. Cuadernos Med Soc 54: 3-14.

Rohwedder RW 1969. Infección chagásica en dadores de sangre y las probabilidades de transmitirla por medio de la transfusión. Bol Chil Parasitol 24: 88-93.

Rosestein Campanini A, Blanco S, Alvarez M, de Rissio AM, Lansetti, JC, Segura EL 1993. Transmision del Trypanosoma cruzy por transfusión de sangre, p. 237 241. In RM Madoery, C Madoery \& MI Camera (eds), Actualizaciones en la Enfermedad de Chagas, Cordoba.

Saez-Alquezor A, Luguetti A, Borges-Pereira J, Moreira EF, Gadelha MFS, Garcia-Zapata MT, Arruda AHS 1997. Estudo multicêntrico: avalição do desempenho de conjuntos diagnósticos de hemoaglutinação indireta, disponíveis no Brasil, para o diagnóstico sorólogico da infecção pelo Trypanosoma cruzi. Rev Patol Trop 26: 343-374.

Saez-Alquezar A, Otani M, Sabino EC, Ribeiro dos Santos G, Salles N, Chamone D 1997. Evaluation of the performance of Brazilian blood banks in testing for Chagas' desease. Vox Sanguinis 74: 228-231.

Salvatella R, Calegari L, Casserone S, Civila E, Carbajal S, Perez G, Somma R, Sampaio I, Lanes ME, Conti IA, Somma Moreira R, Pérez Moreira L 1989. Seroprevalencia de anticuerpos contra Trypanosoma cruzi en 13 departamentos del Uruguay. Bol Of Sanit Panam 107: 108-117.

Schenone H, Alfaro E, Reyes H, Taucher E 1968. Valor del xenodiagnóstico en la infección chagásica crónica. Bol Chil Parasitol 23: 149-154.

Schlemper Jr BR 1978. Estudos experimentais de quimioprofilaxia da transmissão da doença de Chagas por transfussão sangüinea. Rev Pat Trop 7: 55-111.

Schmunis GA 1985. Chagas' disease and blood transfusion, p. 127-145. In RV Dodd \& LF Barker (eds), Infection, Immunity and Blood Transfusion, AR Liss, New York.

Schmunis GA 1989. Chagas' disease and blood transfusion, p. 197-218. In Blood Transfusion and Infectious Diseases, EG Rondanelli, Pichin, Italy.

Schmunis GA 1991. Trypanosoma cruzi, the etiologic agent of Chagas disease: status in the blood supply in endemic and non endemic countries. Transfusion 31: 547-555.

Schmunis GA 1994. American trypanosomiasis as a public health problem. Chagas disease and the nervous system. PAHO Sci Pub 547: 3-29.

Schmunis GA, Zicker F, Pinheiro F, Brandling-Bennett 1998. Risk of transfusion transmitted infectious diseases in Central and South America. Emerg Infect Dis 4: 5-11.

Segura EL, Pérez AC, Yanovsky JF, Andrade J, Wynne de Martini GJ 1985. Decrease in the prevalence of infection by Trypanosoma cruzi (Chagas' disease) in young men of Argentina. PAHO Bull 19: 252-64.

Statistical Abstract of the United States 1992, US Department of Commerce, Washington.

Takei K 1992. Estudo da Eficiência Relativa dos Diferentes Testes Serológicos Utilizados no Diagnóstico da Doenca de Chagas. Resultados Observados na Análise de 10,181 Soros, Thesis, Departamento de Microbiologia e Imunologia, Instituto de Ciencias Biomedicas, Universidade de São Paulo, São Paulo.

Valerio-Wanderley DM, Moraes e Souza H, Gonzalez 
TT, Pereira MSCA 1992. Inquerito sobre a situação do controle do sangue no estado de São Paulo. Rev Soc Brasil Med Trop 25 (Suppl): 35.

Wendell S, Dias JC 1992. Transfusion transmitted Chagas' disease, p. 103-133. In S Wendel, Z Brener, ME Camargo \& A Rassi (eds), Chagas' Disease (American Trypanosomiasis): its Impact on Transfusion and Clinical Medicine, ISBT, São Paulo.
Wendell S, Gonzaga AL1993. Chagas' disease and blood transfusion: A new problem. Vox Sang 64: 1-12.

Zuna H, La Fuente C, Valdez E 1985. Estudio prospectivo de la transmisión del Trypanosoma cruzi por via sanguínea en Bolivia. Ann Soc Belge Med Trop 65 (Suppl. 1): 107-13.

WHO-World Health Organization 1990. The control of Chagas Disease. Tech Rep Ser No. 811. 